\title{
ДИДАКТИЧНІ УМОВИ ФОРМУВАННЯ ПЕДАГОГІЧНОЇ КУЛЬТУРИ МАЙБУТНЬОГО ВЧИТЕЛЯ МУЗИКИ
}

Сидоренко Т. Д. Дидактичні умови формування педагогічної культури майбутнього вчителя музики.

У статті розглядається доцільність організації певної діяльності для іï ефективності та необхідність визначення дидактичних умов реалізації визначеної сукупності процесів, мета яких формування висококваліфікованого спеціаліста.

Ключові слова: дидактичні умови, педагогічна культура, музична культура, музичноестетичне виховання, навчальний процес.

Сидоренко Т. Д. Дидактические условия формирования педагогической культуры будущего учителя музыки.

В статье рассматривается целесообразность организации определенной деятельности для ее эффективности и необходимость выделения дидактических условий реализации определенной совокупности процессов, цель которых - формирование высококвалифицированного специалиста.

Ключевые слова: дидактические условия, педагогическая культура, музыкальная культура, музыкально-эстетическое воспитание, учебный процесс.

Sidorenko T. D. Didactic conditions of formations of pedagogical culture of the future music teachers.

In the article the feasibility of organizing a particular activity for its efficiency and the need for certain conditions for the implementation of teaching a particular set of processes designed to - the formation of a highly qualified professional.

Key words: teaching conditions, pedagogical culture, music culture, music and aesthetic education, the learning process.

Нині не викликає сумніву той факт, що професіоналізм учителя в поєднанні з його творчою індивідуальністю значною мірою підвищують рівень освіченості, особистісного й культурного розвитку учня. Найголовнішу роль у формуванні основ музичної культури відіграє загальноосвітня школа. Саме тут виховується естетичне ставлення до навколишнього світу, формуються якості та властивості особи, що спрямовують i координують їі подальший розвиток.

Школа покликана відкрити перед кожним учнем шлях до пізнання прекрасного, навчити цінувати і розуміти його. Уроки музики так само, як уроки літератури або образотворчого мистецтва, мають бути справжньою школою мистецтва, що дає молоді художній досвід на все життя.

У сучасних умовах особливої актуальності набуває проблема формування педагогічної культури вчителів музики, тому що від рівня особистісного, професійного розвитку педагога-музиканта залежить процес введення дітей у світ музики, залучення до мистецтва, виховання почуттів, розширення їх духовної сфери і професійної.

Метою статті $є$ висвітлення педагогічного досвіду для встановлення сутності педагогічної культури майбутніх учителів музики та виявлення дидактичних умов іiі формування. 
Аналіз філософської, психологічної, педагогічної літератури, а також літератури 3 питань естетики та мистецтвознавства свідчить, що до проблеми формування професійної підготовки майбутніх учителів музики звертаються багато науковців.

Так, К. Ушинський, А. Макаренко, В. Сухомлинський розглядають культуру вчителя, корифеї світової та української сцени К. Станіславський, В. Немирович-Данченко акторську майстерність, О. Абдуліна, А. Алексюк, Є. Барбіна, А. Дьомін, М. Свтух, I. Зязюн, В. Кан-Кальк, Н. Кузьміна, О. Мороз, М. Подберезський, I. Прокопенко, О. Рудницька, В. Сластьонін, Н. Тарасевич, Г. Троцко, Г. Шевченко, О. Щербаков професійну підготовку майбутніх учителів.

До проблеми музично-естетичного виховання особистості й формування іiі музичної культури зверталися Л. Арчажнікова, Ю. Алієв, А. Болгарський, В. Бутенко, Л. Воєводіна, А. Гордійчук, Н. Гродзенська, Л. Коваль, О. Рябініна, Л. Хлєбнікова, В. Шацька. Заслуговують на увагу розробки музикознавців, присвячені питанням теорії та історії музики (О. Апраксіна, Б. Асаф’єв, Н. Ветлугіна, Д. Кабалевський).

У дослідженнях О. Барабанщикова, В. Буряка, Т. Іванової, Є. Гармаш, В. Гриньової, О. Рудницької та ін. з'ясовано, що існують певні умови, за яких найбільш повно виявляється, розвивається, формується педагогічна культура майбутнього вчителя в навчальному процесі. Аналізуючи та узагальнюючи їх теоретичні надбання, спираючись на особисті спостереження, ми зробили спробу репрезентувати систему найбільш загальних i, на наш погляд, найбільш ефективних умов формування цієї якості особистості.

Аналіз психолого-педагогічної літератури свідчить про те, що в процесі організації певної діяльності для її ефективності необхідно враховувати умови реалізації визначеної сукупності процесів.

Нині проблема формування музичної культури майбутнього вчителя музики набула особливої актуальності. Це пов'язано передовсім із тим, що в сучасних умовах унаслідок загострення конкурентної боротьби за ринки збуту i сировину, гонки озброєнь, міжнаціональних військових конфліктів, хижацького ставлення до природи, комерціалізації мистецтва розквітло невігластво. Воно стало реальною загрозою для життя і світової цивілізації. Попередити глобальну катастрофу без опори на духовну культуру не можна. Особлива роль у втіленні гуманістичних ідеалів у життя й діяльність людини належить системі освіти. Через неї проходить більшість населення планети, тому дуже важливо, щоб у цій майстерні працювали носії високої загальної та мистецької культури, здатні формувати у воїх вихованців високу духовність, загальнолюдські цінності, гуманістичні переконання, готовність діяти на спільне благо, залучати молодь до надбань вітчизняного та зарубіжного мистецтва, а саме - вчителі з високим рівнем сформованості музичної культури.

Під музичною культурою особистості ми розуміємо: індивідуальний соціальнохудожній досвід, що зумовлює виникнення високих музичних потреб; властивості особистості, показниками яких є музична розвиненість (любов до музичного мистецтва, уміння емоційно іiі сприймати, потреба в різних зразках художньої музики, музична спостережливість) і музична освіченість (володіння способами музичної діяльності, мистецтвознавчими знаннями, емоційно-ціннісне ставлення до мистецтва i життя, «відкритість» до нових музичних напрямків, знань про сучасне мистецтво, а також стійкість музично-естетичних традицій, художній смак, критичне ставлення до різноманітних музичних явищ).

Професійна підготовка як педагогічна діяльність допускає наявність двох складників суб'єкта і об'єкта, але ці сторони можуть знаходитись у взаєминах тільки у визначеній сфері, визначеному «просторі». Однією із сторін цього «простору» і є дидактичні умови.

Дидактичні умови - система певних форм, методів, матеріальних умов, реальних ситуацій, що об'єктивно склалися чи суб'єктивно створені, необхідних для досягнення конкретної педагогічної мети [2]. 
Водночас дидактичні умови постають формою педагогічної діяльності, мета якої формування висококваліфікованого спеціаліста. Отже, дидактичні умови забезпечують виконання державного стандарту з освітньої діяльності [4].

На наш погляд, необхідно виокремлювати основні компоненти системи, у якій цей процес протікає, розглядати взаємозв'язки між ними і визначати умови ефективного управління ним. Правомірний розгляд системи як елемента системи більш високого порядку. У зв'язку з цим ми розглядаємо навчання у вищій педагогічній школі як систему вищого порядку, яка структурно об'єднує дві взаємопов'язані системи: шкільну і навчання у вищому навчальному закладі, у яких і здійснюється реальне формування педагогічної культури майбутнього вчителя музики.

Ми розглядаємо педагогічну культуру вчителя музики як систему музичнопедагогічних, мистецьких знань, умінь і навичок, яка виявляється в інтегруючій здатності здійснювати музичне навчання й виховання дітей на основі художньо-педагогічного спілкування. Вона відображає зміст, обсяг, якість та системність педагогічних, музичних та мистецьких знань та умінь, що дозволяють учителю повною мірою реалізувати свій творчий потенціал.

Провівши анкетування серед учителів та студентів щодо формування в них музичної культури, ми виявили суперечність між необхідністю високого рівня сформованості педагогічних здібностей, знань, умінь, особистісних якостей, настанов на сприйняття дитини як цінності та відсутністю його в реальній практиці.

Ця суперечність може бути подолана в процесі навчання студентів у вищому педагогічному навчальному закладі.

Структура та зміст педагогічної підготовки вчителя музики визначаються Державними стандартами для різних спеціальностей, навчальними планами та навчальними посібниками 3 педагогічних та мистецьких дисциплін. Проспостерігаємо, як у них розв'язується досліджувана проблема.

Не зважаючи на те, що в умовах перебудови загальноосвітньої та професійної школи перед вищою школою поставлено завдання критичного переосмислення всього набутого досвіду, глибокого аналізу багатолітньої практики викладання педагогічних дисциплін, передачі школі ії культуро-творчої функції, радикальних позитивних змін не відбулося.

Проблема підвищення ефективності та якості професійної підготовки майбутніх учителів музики може бути вирішена тільки шляхом удосконалення навчального процесу, яке здійснюється через упровадження нових форм і методів, оптимізації змісту навчання. Ключем до вирішення цієї проблеми, на наш погляд, є підпорядкування всієї діяльності викладачів і студентів досягненню загальної мети - формуванню педагогічної культури майбутніх учителів музики [1].

Аналіз Державних стандартів з педагогічних дисциплін, навчальних посібників 3 педагогіки, культурології, художньої культури для студентів, опитування вчителів та студентів, досвід багаторічних спостережень дозволяють нам уважати, що формування досліджуваної соціальної якості майбутніх учителів музики буде успішним за реалізації таких дидактичних умов: здійснення «наскрізного» підходу до розв'язання проблеми: спрямованість усіх ланок, елементів навчально-виховного процесу на досягнення головної та єдиної мети - підготовки вчителя музики з високим рівнем сформованості педагогічної культури; організація навчально-виконавської діяльності; розвиток емоційно-ціннісного ставлення студентів до явищ музичної культури; оволодіння студентами засобами й уміннями художньо-педагогічного спілкування з дітьми; формування й розвиток навичок педагогічної інтерпретації навчального матеріалу; реалізація програми поетапного формування педагогічної культури майбутнього вчителя музики в процесі вивчення педагогічних, мистецьких, культурологічних дисциплін; створення ситуацій творчої самореалізації та самовираження в навчальному процесі; більш повне використання потенційних можливостей педагогічно-мистецьких дисциплін задля формування в студентів цієї якості особистості; мобілізація можливостей педагогічної практики 3 
орієнтацією на модель учителя музики високої педагогічної культури (культура - поняття діяльне, вона виявляється та формується тільки в діяльності); використання спецсемінарів та спецпрактикумів, зорієнтованих на формування досліджуваної якості особистості майбутнього вчителя музики.

Для того, щоб реалізація вище зазначених умов була успішною, необхідне виконання викладачами педагогічних та мистецьких дисциплін певних навчально-виховних функцій, які передбачає діяльність викладачів на цільовому, процесуальному та контрольноаналітичному рівнях:

- діагностична (вивчення студентів, зокрема, мотивів вступу до вищого навчального педагогічного закладу; попередній досвід спілкування з дітьми; професійно-педагогічна спрямованість особистості; умови сімейного виховання тощо) для визначення мети та завдань роботи в конкретних умовах, з конкретною групою студентів;

- мобілізаційно-спонукальна (формування у студентів «виховної мобільності» - їхньої готовності та здатності до сприйняття виховних дій; створення установки на прийняття моделі вчителя музики 3 високим рівнем сформованості педагогічної культури та готовності до її засвоєння на особистісній основі);

- комунікативна (встановлення педагогічно доцільних взаємовідносин);

- організаторська (створення умов, необхідних для реалізації «глобальної» мети формування особистості вчителя музики з високим рівнем сформованості педагогічної культури);

- формувальна, або процесуальна (переведення цілей програми з підготовки вчителя музики з високим рівнем сформованості педагогічної культури в цільову орієнтацію студентів);

- контрольно-аналітична та оцінна (контроль, аналіз та оцінка ефективності навчально-виховної роботи, iї корекція та вдосконалення: пошук нових форм та методів роботи).

Ця система функцій цілісно відображає структуру та динаміку професійної діяльності викладача в навчально-виховному процесі. Ефективність роботи під час реалізації моделі поетапного формування педагогічної культури майбутнього вчителя музики залежить від комплексного виконання викладачами визначених функцій.

Проведена нами робота не вичерпує всіх аспектів цієї проблеми. Подальшого дослідження та наукового обгрунтування потребують: вивчення функцій різних видів музично-педагогічної діяльності у процесі формування музично-педагогічної культури майбутніх учителів музики, формування музично-педагогічних здібностей учителя музики, вплив педагогічної практики на формування готовності майбутніх учителів до професійної діяльності.

\section{Література}

1. Букач М. М. Формування педагогічної культури вчителя музики засобами спеціальних практик / Микола Миколайович Букач. - Одеса : Логос, 1997. - 196 с. 2. Кагальняк Г. І. Педагогічні умови активізації професійно важливих якостей учителів / Г. І. Кагальняк, О. О. Ящишин // Психологія: [збірник наукорвих праць]. - К., 1991. - Вип. 36.- С. 82-90. 3. Назаренко Н. В. Буденно-музична свідомість як предмет філософсько-естетичного аналізу: автореф. дис. на здобуття наук. ступеня канд. філософ. наук : спец. : 09.00 .08 «Естетика» / Н. В. Назаренко. - Луганськ, 2006. - 20 с. 4. Рудницька О. П. Формування музичного сприйняття в системі розвитку педагогічної культури майбутнього вчителя: автореф. дис. на здобуття наук. ступеня док.пед.наук : спец. : 13.00 .01 - «Теорія та історія педагогіки» / О. П. Рудницька. - К., 1994. - 42 с. 5. Чередниченко Т. В. Эстетика музыкальная / Т. В. Чередниченко // Музыкальная энциклопедия: В 6 т. / [гл. ред. Ю. В. Келдыш]. - Москва: Советская энциклопедия, 1982. - Т. 6: Хейнце - Яшугин. - С. 554-566. 